\title{
Probabilistic Seismic Hazard Analysis for Northern Tanzania Divergence Region and the Adjoining Areas
}

\author{
Michael M. Msabi ${ }^{1 *}$ and Richard W Ferdinand ${ }^{2}$ \\ ${ }^{1}$ Department of Geology, University of Dodoma, Dodoma, Tanzania \\ ${ }^{2}$ Department of Geosciences, University of Dar es Salaam, Dar es Salaam, Tanzania \\ E-mail: rfwambura@gmail.com
}

*Corresponding author, e-mail addresses: msabimichael@gmail.com; mmsabi@yahoo.com

Received 26 Mar 2021, Revised 29 May 2021, Accepted 30 May 2021, Published May 2021

DOI: https://dx.doi.org/10.4314/tjs.v47i2.40

\begin{abstract}
This paper presents the seismic hazard levels for the Northern Tanzania Divergence (NTD) and adjoining areas by using area seismic source zones. The 15 source zones were considered based on the major geological and tectonic features, faulting style, and seismicity trends. For each source, earthquake recurrence parameters were computed by using the earthquake catalogue with events compiled from 1956 to 2011. The peak ground accelerations (PGA) and spectral accelerations (SA) at 0.2 and 2.0 second, respectively, were computed for a $10 \%$ probability of exceedance in 50 years at sites defined by a $0.1^{\circ}$ x $0.1^{\circ}$ grid. The recurrence parameters of 15 zones and attenuation relations developed by Akkar et al. (2014) and Chiou and Youngs (2014) were integrated into a logic tree. Obtained results that are presented as hazard maps show strong spatial variations ranging from 60 to $330 \mathrm{~cm} / \mathrm{s} / \mathrm{s}$ for PGA, from 100 to $650 \mathrm{~cm} / \mathrm{s} / \mathrm{s}$ at $0.2 \mathrm{sec}$ and from 6 to $27 \mathrm{~cm} / \mathrm{s} / \mathrm{s}$ at $2 \mathrm{sec}$ for 475 years mean return period and 5\% damping. Hazard levels depict the general tectonic setting of the study area with the western (Eyasi-Wembere) and central (Natron-ManyaraBalangida) rift segments having relatively high PGA values compared with the eastern Pangani rift. This work provides indications of seismic hazards to policymakers and planners during planning and guidelines for earthquake-resistant design engineers.
\end{abstract}

Keywords: Homogeneous Earthquakes Catalogue; GMPE; PSHA; NTD.

\section{Introduction}

A seismically active East African rift system (EARS) that is part of the global divergent tectonic plate boundaries traversing Tanzania is marked by the frequent occurrence of large and moderate magnitude earthquakes. The occurrence of these earthquakes can threaten a growing urban population if proper analysis of seismic hazard levels is not addressed. A good example of threats occurred in 2003 when two earthquake events of similar magnitudes to those that occurred in Lake Eyasi, $1964(\mathrm{Mw}=6.4)$, and Lake Tanganyika, $2005(\mathrm{Mw}=6.8)$, shook the city of Algiers in
Algeria. The event claimed the lives of 2,273 people, 8,000 injuries, left more than 200,000 homeless, while the total estimated economic impact was about US $\$ 65$ billion, or roughly $10 \%$ of Algeria's total GDP (EERI 2003, Bouhadad et al 2004).

Records of the damaging earthquakes in Tanzania can be traced back to colonial times. Records show the 1910 Rukwa earthquake (Ms 7.4) attacked the country and badly strained all European-styled stone structure houses along the eastern shore of Lake Tanganyika (Ambraseys 1991). The Lake Eyasi, 1964 earthquake $\left(\mathrm{M}_{\mathrm{b}}=6.4\right)$ caused a building 
collapse, which killed scores of people in the Mbulu District. Despite its small size, the Rungwe earthquake sequence of 2000-2001 $(\mathrm{Mb}=4.6$ as maximum), reported damages of about 600 houses and devastating more than 6000 people (Fontijn et al. 2010). A 2002 moderate earthquake $(\mathrm{Mb}=5.6)$ near Dodoma town strained a parliament building. The 2005 Lake Tanganyika earthquake event $(\mathrm{Mw}=6.8)$, claimed the lives of 13 people in Kalemie in Democratic Republic of Congo, collapsed several brick house buildings along the eastern shore of Lake Tanganyika in Tanzania, and shook some highly raised buildings in distant cities as far as $1000 \mathrm{~km}$ away (Ferdinand and Nderimo 2007). The Lake Natron, 2007 earthquake sequence ( $\mathrm{Mw}$ 5.9) caused damages to Arusha city (70 km away) and shook the highly raised buildings, causing panic attack on cities around East Africa (Ferdinand et al. 2007). Recently, the Kagera earthquake of $2016(\mathrm{Mw}=5.9)$ at the border of Tanzania and Uganda claimed the lives of 17 people in Bukoba town (40 km away) and millions of US dollars in property loss (Ferdinand et al. 2017, Mulibo 2019) (Figure 1).

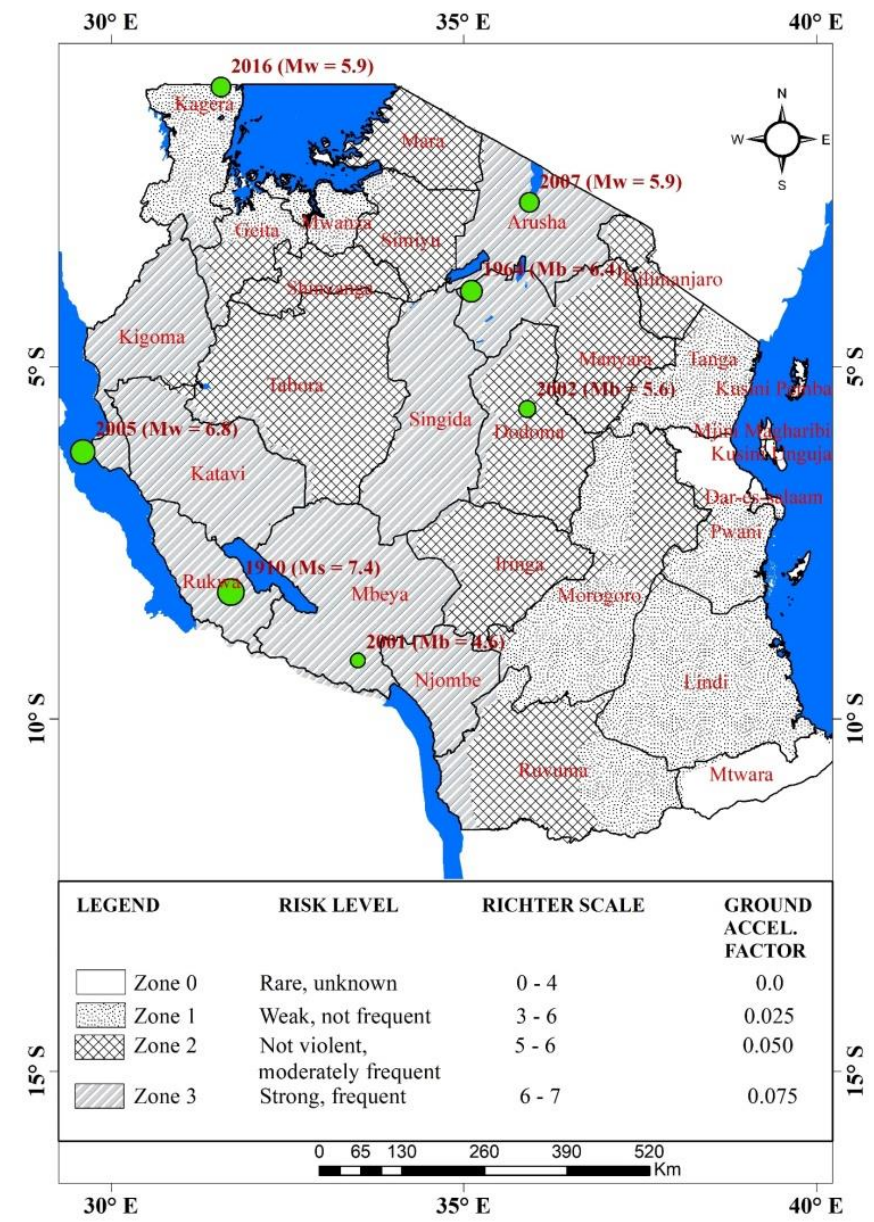

Figure 1: Earthquake Distribution for construction building code in Tanzania (Modified after NHBRU Technical Guideline No. 2 (Second Edition)). Green dots indicate damaging earthquake events recorded in Tanzania. 
Msabi and Ferdinand - Probabilistic seismic hazard analysis for Northern Tanzania ...

The events in Tanzania seem to have caused relatively small losses compared with events of similar sizes in North Africa because of the low population in Tanzanian urban centres. With the expansion of urban centres, building methods are likely to change from traditional fabrics with an inherent resistance to earthquake shaking to modern masonry constructions, which are more vulnerable to shaking. The prevalence of earthquakes in Tanzania, therefore, signifies the importance of establishing seismic hazard levels at different sites of national interest.

For many years, the construction industry in Tanzania has operated by using construction codes that do not reflect the true effects of earthquake-strong ground motion that are linked to seismic source zones of specific sites (Figure 1). The seismic factor that is currently used in construction codes is based on compiled physical responses to earthquakes felt by people at different places within the country (NHBRU 2015). Based on those responses, Tanzania is divided into four zones, of which, the third and fourth zones (Zone 2 and 3) dominate the Northern Tanzania Divergence (NTD), along the eastern branch of the EARS. Geographically, the NTD occupies seven out of twenty-six regions that constitute Tanzania's mainland (Figure 2). With different distributions of seismic source zones around regional centres and variations of site conditions among them, a uniform seismic factor is not realistic. For instance, a peak ground motion, PGA, at Babati town, surrounded by Eyasi, Yaida, and Manyara faults, may not be the same as the Dodoma City that is surrounded by Kwamtoro, Bubu, and Sanzawa faults (Msabi 2016). While the Arusha City is underlined by thick volcanic sediments of the order of $200 \mathrm{~m}$ (DDCA 2002), the Dodoma City is underlined by shallow alluvial sediment of the order of less than $15 \mathrm{~m}$ (Ferdinand et al. 2018, 2020). The surface ground motion at these sites may be different as they are computed from the distance and distribution of seismic sources with respect to sites and the type and thickness of the sediment underlying the site.

This study aimed to address the problem explained above by establishing the seismic hazard levels of NTD by using the probabilistic seismic hazard analysis (PSHA) methodology. The scope of the PSHA in this study included; to identify and characterize seismic sources within NTD and surrounding areas, selection of appropriate ground motion prediction equations (GMPEs) for NTD, and estimation of peak ground acceleration (PGA) and hazard levels at different periods for $10 \%$ probability of exceedance in 50 years. The established ground shaking levels at particular sites will enable engineers, planners, insurers, and decisionmakers to have better judgments on how and where within NTD to put infrastructures.

\section{Geological and Tectonic Setting}

NTD lies along the Eastern branch of the East African rift system (EARS). The Cenozoic EARS constitutes the longest example of a continental narrow rift, running for $\sim 3000 \mathrm{~km}$ from Afar triple junction in Ethiopia to the Zambezi valley in southern Mozambique. Along with its course, the EARS includes three well-defined rift segments, namely the Main Ethiopian Rift (MER), the Western branch (WB), and the Eastern Branch (EB). The EB is tectonically divided into the northern (Kenyan rift) and the southern part (Tanzanian segment) with the assumed region of separation along the E-W line of the volcanic center of Northern Tanzania (Fairhead and Stuart 1982). The Tanzanian segment has developed in the Archean lithosphere in the west (EyasiWembere rift) and in Late Proterozoic (PanAfrica) orogenic belts along its central (Manyara-Balangida rift) and the eastern limb (Pangani rift) (Foster et al. 1997). Based on this division the northern Tanzania section is referred to as the Northern Tanzania Divergence (NTD). In the NTD, the three rift arms are arranged within a nearly $300 \mathrm{~km}$-wide zone of deformation. Their basement deformation history is relatively well established (McConnell 1972), as well as the 
deep structure of the western and central rift arms (Ebinger et al. 1997). The Pangani rift arm extends over $200 \mathrm{~km}$ at NNW-SSE, immediately south of the Kilimanjaro volcano. It comprises three main discrete blocks, separated by transverse depressed zones and increasing topographic elevation southwards from $1600 \mathrm{~m}$ in the North Pare Mountains to
$2100 \mathrm{~m}$ in the Usambara Mountains. The elongated high zone corresponds to an asymmetric faulted block. The Pangani arm is considered to be less seismically active as compared to the other two arms (Ebinger et al. 1997, Msabi 2010, 2016). Along Pangani, volcanism is restricted to Late Pliocene to recent (Foster et al. 1997).

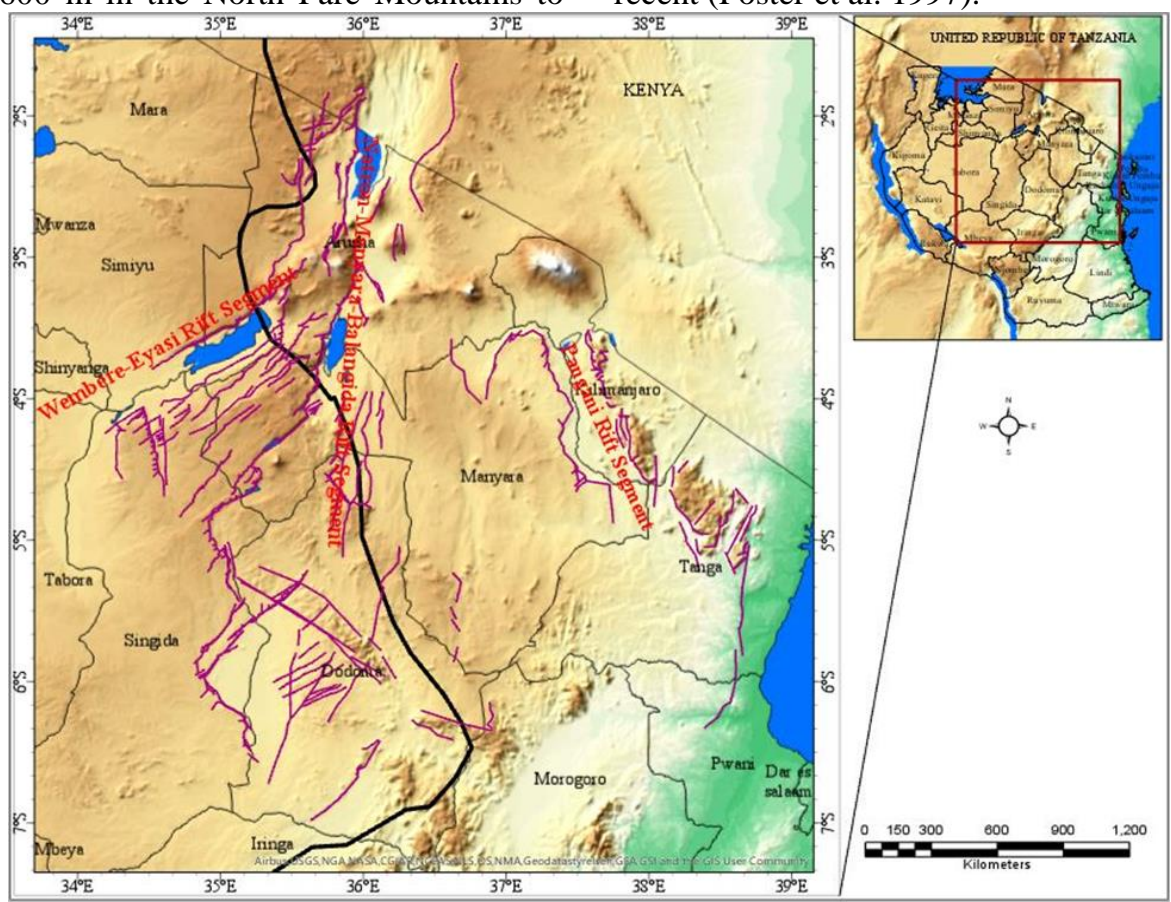

Figure 2: The major rift segments with their border faults within the Northern Tanzania Divergence. A dark solid line indicates the boundary between the Archean Tanzanian craton (on the west)-Proterozoic Mozambique mobile belt (on the east).

The Manyara-Balangida rift is composed of Manyara fault and Balangida fault. The $120 \mathrm{~km}$ long Manyara fault trends NNE-SSW, while the Balangida fault trends NE-SW. The present-day Manyara escarpment formed after a major phase of a volcanic eruption at $\sim 1.2$ Ma (Dawson 1992, Foster et al. 1997). Volcanism within Balangida began in Pliocene time (Foster et al. 1997). The Eyasi arm can be traced through the nearly linear extended Eyasi fault. The NE-SW trending fault is more than $90 \mathrm{~km}$ long. The uplifted block is composed of Archean basement rocks.
Looking at the seismicity, the NTD shows high seismic activities that spread out over a much wide-area (Bungum and Ringdal 1982, Msabi 2016) with Manyara and Eyasi rift segments dominating. The largest recorded earthquake occurred in this area on May $7^{\text {th, }}$ 1964, with a magnitude of 6.4 (Iranga 1991). Accurate earthquake depth determination from waveform analysis (Nyblade and Langston 1995, Foster and Jackson 1998), together with a micro-earthquake survey (Nyblade et al. 1996) revealed the seismogenic thickness down to $35 \mathrm{~km}$. Such depth could suggest a thick and strong crust that can accommodate brittle 
Msabi and Ferdinand - Probabilistic seismic hazard analysis for Northern Tanzania ...

failure. The distribution of the fault plane solutions shows that within the NTD the focal mechanisms are predominantly normal with some few strike-slip faults (Shudofsky 1985 , Foster and Jackson 1998, Brazier et al. 2005, Daudi 2007, Msabi 2016). The extension direction in the Manyara arm is WNW-ESE consistent with the general trend of the EARS (Daudi 2007). The extension direction changes as the rift encounters the Tanzanian Craton to the south of Manyara (Daudi 2007). Based on the direction of the tensional stresses deduced from fault plane solution, Daudi (2007) grouped the Manyara-Balangida and Eyasi arms into three earthquake source zones, i.e., the WNW- Manyara, the NE- Eyasi, and the EKondoa zones indicating a rotation as the rift encounter the Craton boundary from Orogenic belt.

\section{Materials and Methods \\ Probabilistic Seismic Hazard Analysis (PSHA) methodology}

PSHA is frequently used to evaluate the seismic design load for critical engineering projects. PSHA method was initially developed by Cornell $(1968,1971)$ and later by McGuire (1976) as a means of characterizing the level of ground motion to an area for a given period. The main goal of PSHA is to quantify seismic hazard uncertainties and combine them to produce an explicit description of the distribution of future ground shaking at a site of interest. In this approach, the seismic hazard is defined as the probability that a certain level of ground motion will be exceeded at a given place and period. PSHA integrates seismic source zones, earthquake recurrence relation parameters, and the ground motion prediction equations to produce hazard levels in terms of PGA and spectral acceleration at different ordinances. In this study, The Peak Ground Accelerations (PGA) and spectral accelerations (SA) at structural ordinates 0.2 and 2.0 seconds, respectively, were computed for $10 \%$ probability of exceedance (i.e., $90 \%$ chance of non-exceedance) in 50 years or a return period of 475 years, at sites defined by $0.1^{\circ} \times 0.1^{\circ}$ grid using R-CRISIS Ver. 20.1.1 software (Ordaz and Salgado-Gálvez 2019).

\section{Seismic sources models}

Seismic sources in this study were modeled based on the existing published literature on active faults (Msabi 2010, 2016), seismotectonic study (Daudi 2007), and available earthquake records of the study area (Table 1). The selection criteria of the source zones were based on the style of faulting (Figure 3) and the distribution of earthquake clusters (Figure 4). Two styles of faulting are dominant in NTD, namely normal and strikeslip faulting (Figure 3). The observed prevalent direction of crustal extension is reflected by normal faulting which is dominant during rifting, while the interaction at a boundary between a Craton and a Mozambique mobile belt is probably reflected by the strike-slip faulting mechanisms (Figure 3).

Earthquake data used in this study were compiled from different sources of information and covered a period of 56 years, from 1955 to 2011 (Table 1). These events were merged and reformatted to prepare a homogenized composite earthquake catalogue. The data from this catalogue were then declusted by using the Gardner and Knopoff (1974) technique to remove dependent events. For this catalogue to be used in the prediction of the occurrence of future earthquakes (recurrence relation), the level of temporal completeness has to be tested. In this study, the level of completeness was deduced from the tabulation of magnitude class versus period (Table 2). From the table, it can be seen that for all periods, the magnitude class $\mathrm{E}$ has the maximum number of earthquake occurrences with exception of the period between 1955 and 1993 when the station coverage was poor in the area. This implies that below this class, the detection threshold is low and above it, the selected window of observation (1955-2011) is not long enough for a significant number of moderate to the large event to be observed. Hence it sets the level of completeness of the catalogue at a minimum magnitude of Mw 4.1. 


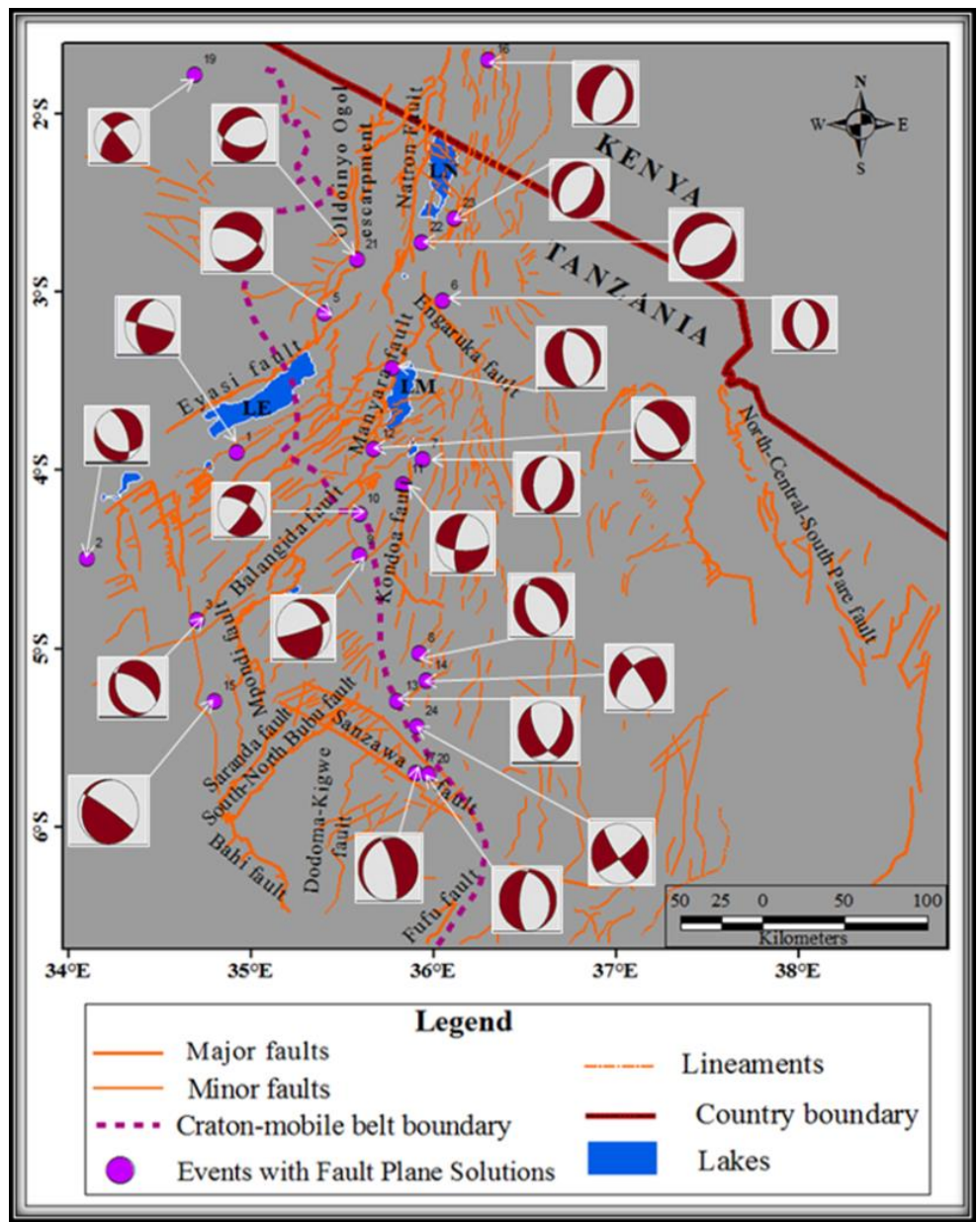

Figure 3: The distribution of fault plane solutions within NTD.

Table 1: Summary of the earthquake data sources

\begin{tabular}{|c|c|c|}
\hline $\mathbf{S} / \mathbf{N}$ & Data source & Period covered \\
\hline 1 & International Seismological Center (ISC) catalogue & $1955-2011$ \\
\hline 2 & Harvard Centroid Moment Tensor (CMT) catalogue & 1976-2011 \\
\hline 3 & Earthquake Catalogue for Tanzania (Iranga 1991) & $1955-1986$ \\
\hline 4 & $\begin{array}{llll}\text { National Earthquake } & \text { Information } & \text { Centre } & \text { (NEIC)/USGS } \\
\text { Comprehensive catalogue }\end{array}$ & $1973-2009$ \\
\hline 5 & $\begin{array}{l}\text { Eastern and Southern Africa Regional Seismological Working Group } \\
\text { (ESARSWG) bulletins }\end{array}$ & 1993-1999 \\
\hline 6 & $\begin{array}{l}\text { Tanzania Broadband Seismic Experiment } \text { (TBSE) catalogue } \\
\text { (Nyblade et al. 1996) }\end{array}$ & 1994-1995 \\
\hline 7 & $\begin{array}{l}\text { Kenya Seismological Network (KSN) catalogue (Hollnack 1996, } \\
\text { Hollnack and Stangl 1998) }\end{array}$ & $1995-1998$ \\
\hline 8 & $\begin{array}{l}\text { Africa Array Seismographs Network (AASN) catalogue (Mulibo } \\
\text { 2012) }\end{array}$ & 2009-2011 \\
\hline 9 & Northern Tanzania Divergence (NTD) catalogue (Msabi 2016) & $2005-2010$ \\
\hline
\end{tabular}


Msabi and Ferdinand - Probabilistic seismic hazard analysis for Northern Tanzania ...

Table 2: Number of earthquakes in the homogenized declustered catalogue for NTD reported time intervals from 1955 to 2011 grouped in nine magnitude classes

\begin{tabular}{|c|c|c|c|c|c|c|c|c|c|c|}
\hline \multirow{2}{*}{ Period } & \multicolumn{9}{|c|}{ Magnitude class } & \multirow{2}{*}{$\mathbf{N}$} \\
\hline & $\mathbf{A}$ & B & $\mathbf{C}$ & D & $\mathbf{E}$ & $\mathbf{F}$ & $\mathbf{H}$ & $\mathbf{I}$ & $\mathbf{J}$ & \\
\hline $1955-1993$ & 1 & 1 & 6 & 15 & 117 & 144 & 91 & 3 & 1 & 379 \\
\hline 1994-1999 & 7 & 46 & 87 & 610 & 676 & 81 & 21 & 0 & 0 & 1528 \\
\hline $2000-2006$ & 0 & 0 & 0 & 0 & 69 & 8 & 3 & 0 & 0 & 80 \\
\hline $2007-2007$ & 0 & 0 & 0 & 11 & 177 & 157 & 15 & 1 & 0 & 361 \\
\hline $2008-2011$ & 0 & 0 & 9 & 42 & 200 & 92 & 12 & 3 & 0 & 358 \\
\hline Total & 8 & 47 & 102 & 678 & 1239 & 482 & 142 & 7 & 1 & 2706 \\
\hline
\end{tabular}

(Where: $\mathbf{A} \leq 2.5, \mathbf{B}=2.6 \leq \mathrm{M}_{\mathrm{w}} \leq 3.0, \mathbf{C}=3.1 \leq \mathrm{M}_{\mathrm{w}} \leq 3.5, \mathbf{D}=3.6 \leq \mathrm{M}_{\mathrm{w}} \leq 4.0, \mathbf{E}=4.1 \leq \mathrm{M}_{\mathrm{w}} \leq 4.5, \mathbf{F}=$ $4.6 \leq \mathrm{M}_{\mathrm{w}} \leq 5.0, \mathbf{H}=5.1 \leq \mathrm{M}_{\mathrm{w}} \leq 5.5, \mathbf{I}=5.6 \leq \mathrm{M}_{\mathrm{w}} \leq 6.0, \mathbf{J}=6.1 \leq \mathrm{M}_{\mathrm{w}} \leq 6.5$ and $\mathbf{N}=$ Total Number of Earthquakes per time interval).

In total, NTD is divided into fifteen area seismic source zones. The majority of source zones in this study are rift basins bounded by major rift boundary fault segments (Figure 4). These include Natron (Z2), Engaruka (Z4), Manyara (Z5), Eyasi (Z6), Balangida (Z8),
Kondoa (Z13), Mpondi (Z9), Bahi-Dodoma (Z10), Sanzawa (Z11), KwaMtoro (Z12) and Pare (Z15). Others are blocks with randomly distributed earthquakes like Ngorongoro (Z1), Iramba (Z7), Kilimanjaro (Z3), and Masai (Z14) (Figure 4).

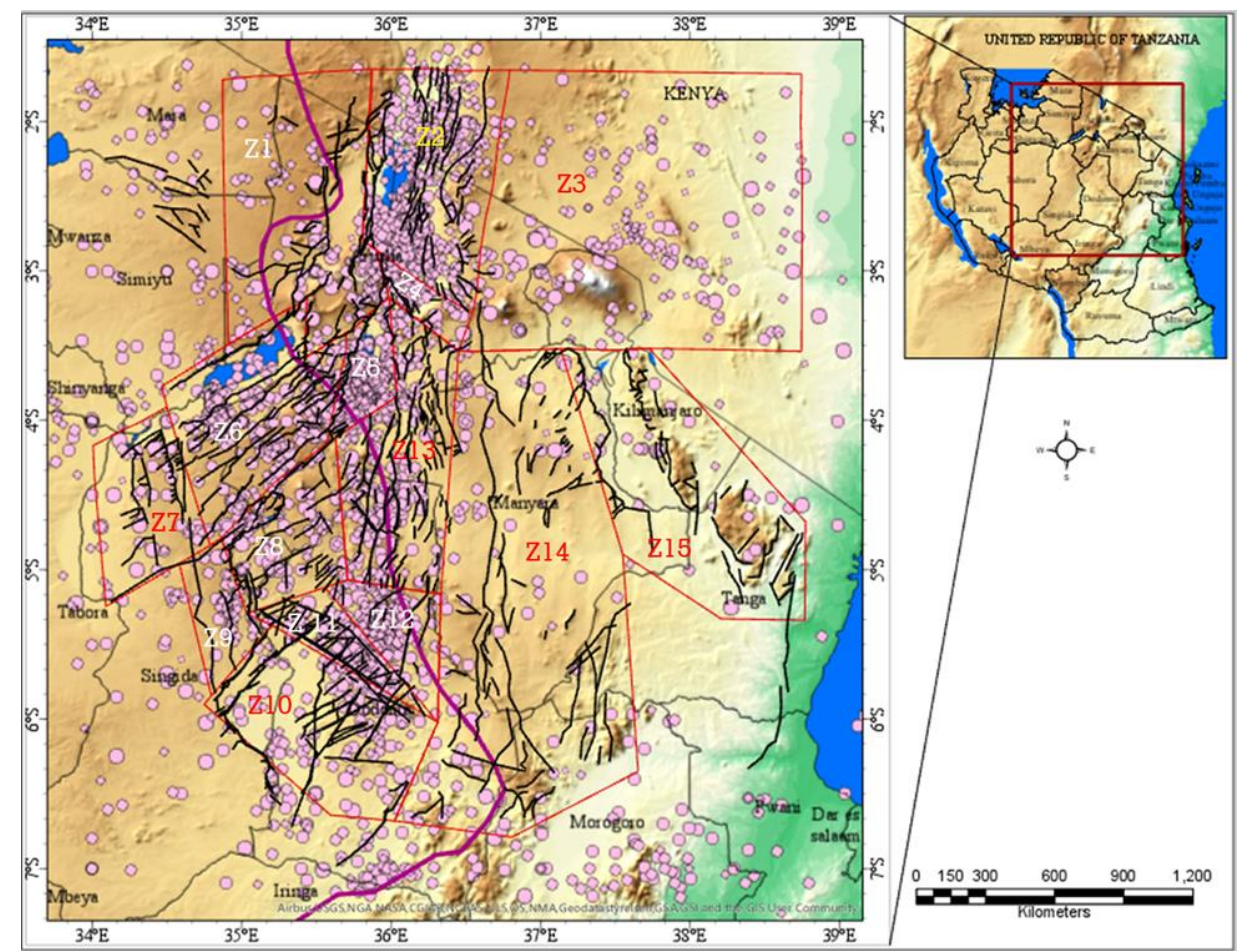

Figure 4: The delineated area seismic source zones within NTD and adjacent areas. 


\section{Recurrence relation model}

The earthquake records of the declustered catalog that pass a completeness test are used to estimate the parameters of the recurrence relation, i.e., a- and b-values (Gutenberg and Richter 1944). The maximum likelihood technique (Weichert 1980) was employed for calculating the $a$ - and b-values, by setting the magnitude bin to 0.1 for each of the 15 source zones. The procedure was; after calculating the b-value, its value was fixed and the activity rate (a-value) was calculated by assuming a $\mathrm{M}_{\text {min }}$ value of $M_{w}=4.1$. The Wizmap II Software Package developed by Musson (1998) was applied to estimate the cumulative frequency parameters $a$ - and $b$-value of the recurrence relationship. Results for all the 15 seismic zones are tabulated in Table 3.

Table 3: Summary of the recurrence parameters used to characterize each source zone used as inputs in the computational algorithm of the probabilistic seismic hazard analysis for NTD

\begin{tabular}{|c|c|c|c|c|c|c|c|c|c|c|c|c|c|}
\hline \multirow[b]{3}{*}{$\mathbf{S} / \mathbf{N}$} & \multicolumn{13}{|c|}{ Seismicity parameters for seismic source zones } \\
\hline & \multicolumn{7}{|c|}{ From Kijko's statistical code } & \multicolumn{6}{|c|}{ From adding 0.5 of a unit magnitude } \\
\hline & $\begin{array}{c}\mathrm{M}_{\max }, \\
\text { calc }\end{array}$ & $\begin{array}{c}\mathrm{SD} \text { in } \mathrm{M}_{\max } \\
\text { calc }\end{array}$ & $\mathrm{b}$ & $\mathrm{SD}$ in $\mathrm{b}$ & $\beta$ & $\mathrm{SD}$ in $\beta$ & $\mathrm{a}$ & $\mathrm{M}_{\max , \text { calc }}$ & $\mathrm{b}$ & $\pm \mathrm{b}$ & a & $\pm \mathrm{a}$ & $\beta$ \\
\hline $\mathrm{Z} 1$ & 5.61 & 0.15 & 0.73 & 0.13 & 1.6809 & 0.21 & 1.82 & 6.0 & 0.81 & 0.13 & 3.35 & 0.62 & 1.87 \\
\hline $\mathrm{Z} 2$ & 6.16 & 0.28 & 1.03 & 0.08 & 2.3717 & 0.19 & 2.21 & 6.4 & 1.15 & 0.06 & 5.23 & 0.29 & 2.65 \\
\hline $\mathrm{Z3}$ & 5.58 & 0.13 & 0.78 & 0.08 & 1.7960 & 0.19 & 1.99 & 6.0 & 0.82 & 0.17 & 3.52 & 0.81 & 1.89 \\
\hline $\mathrm{Z4}$ & 5.43 & 0.17 & 0.97 & 0.13 & 2.2335 & 0.29 & 1.78 & 5.8 & 0.99 & 0.12 & 4.05 & 0.53 & 2.28 \\
\hline $\mathrm{Z} 5$ & 5.22 & 0.10 & 0.86 & 0.06 & 1.9802 & 0.14 & 2.34 & 5.7 & 1.24 & 0.14 & 5.67 & 0.65 & 2.86 \\
\hline $\mathrm{Z6}$ & 7.03 & 0.54 & 0.89 & 0.07 & 2.0493 & 0.16 & 2.28 & 7.0 & 1.02 & 0.05 & 4.60 & 0.24 & 2.35 \\
\hline $\mathrm{Z7}$ & 5.40 & 0.14 & 0.58 & 0.10 & 1.3355 & 0.10 & 1.57 & 5.8 & 0.68 & 0.10 & 2.58 & 0.47 & 1.57 \\
\hline Z8 & 5.60 & 0.14 & 0.77 & 0.09 & 1.7730 & 0.20 & 1.90 & 5.8 & 0.96 & 0.07 & 3.57 & 0.36 & 2.21 \\
\hline Z9 & 6.14 & 0.55 & 1.64 & 0.24 & 3.7762 & 0.56 & 1.65 & 5.7 & 0.96 & 0.07 & 4.19 & 0.42 & 2.21 \\
\hline $\mathrm{Z} 10$ & 5.35 & 0.11 & 0.73 & 0.08 & 1.6809 & 0.18 & 1.99 & 5.8 & 0.98 & 0.18 & 4.17 & 0.85 & 2.26 \\
\hline Z11 & 5.13 & 0.11 & 0.84 & 0.08 & 1.9342 & 0.19 & 2.08 & 5.6 & 1.11 & 0.17 & 4.91 & 0.75 & 2.56 \\
\hline $\mathrm{Z} 12$ & 5.93 & 0.17 & 0.97 & 0.07 & 2.2335 & 0.17 & 1.99 & 6.3 & 1.28 & 0.08 & 6.03 & 0.17 & 2.95 \\
\hline Z13 & 5.65 & 0.11 & 0.77 & 0.06 & 1.7730 & 0.13 & 2.32 & 6.1 & 1.09 & 0.19 & 4.92 & 0.90 & 2.51 \\
\hline Z14 & 5.59 & 0.13 & 0.66 & 0.08 & 1.5197 & 0.19 & 1.88 & 6.0 & 0.99 & 0.13 & 3.94 & 0.62 & 2.28 \\
\hline $\mathrm{Z} 15$ & 5.65 & 0.27 & 0.80 & 0.15 & 1.8421 & 0.35 & 1.48 & 5.9 & 0.99 & 0.13 & 3.39 & 0.36 & 2.28 \\
\hline
\end{tabular}

\section{Ground motion prediction equations (GMPEs)}

GMPEs associate a ground-motion parameter, e.g., spectral acceleration (SA), peak ground acceleration (PGA), peak ground velocity (PGV), among others to a set of variables defining the earthquake source, wave propagation path, and local site conditions (Douglas 2003). In the PSHA study, they predict the expected ground motion at a site in a given distance from an earthquake of a given magnitude, usually expressed as moment magnitude. Based on the tectonic regime, Abrahamson and Shedlock (1997) grouped GMPEs into three major groups, i.e., GMPEs for earthquakes occurring in the subduction zones, in the stable continental regime, and for shallow crustal earthquakes in extension tectonic regime. The NTD exhibits tectonic behaviour similar to that of shallow crustal extensional tectonic regimes. However, limitations to develop GMPE for the extensional regime of the EARS region due to lack of strong-motion data led to adoption of the existing GMPEs from other regions of the similar tectonic regime. The general criteria for adopting GMPEs, include consideration of the following topics, geology, tectonic setting, style of faulting, type of seismic sources, magnitude range, the distance between the site and seismic source, and period. Two GMPEs were adopted in this study (Akkar et al. 2014, Chiou and Youngs 2014) based on selection criteria proposed by Bommer et al. (2010). 


\section{Uncertainty}

During any seismic hazard analysis, uncertainties of the input datasets must be considered. There are two types of uncertainties: aleatory and epistemic. The aleatory uncertainty is considered through the standard deviation of residuals in the GMPEs, while the logic tree approach helps to minimize the epistemic uncertainties (Bommer et al. 2005). In a logic tree, the relative confidence of the analyst in the options is achieved by selecting alternative models or model parameters for various inputs to assign weights to different branches at each node. Hazard calculations from each model are then combined using various schemes that produce a weighted mean (or median) hazard value. In the logic tree approach sum of the weighting factor for all the branches at each node should be equal to unity. The nodes of the logic tree employed in this study include the seismic source model, attenuation model, maximum magnitude, earthquake recurrence parameter, and focal depth. The schematic sketch of a logic tree model developed for this study along with the weighting for each branch are shown in Figure 5.

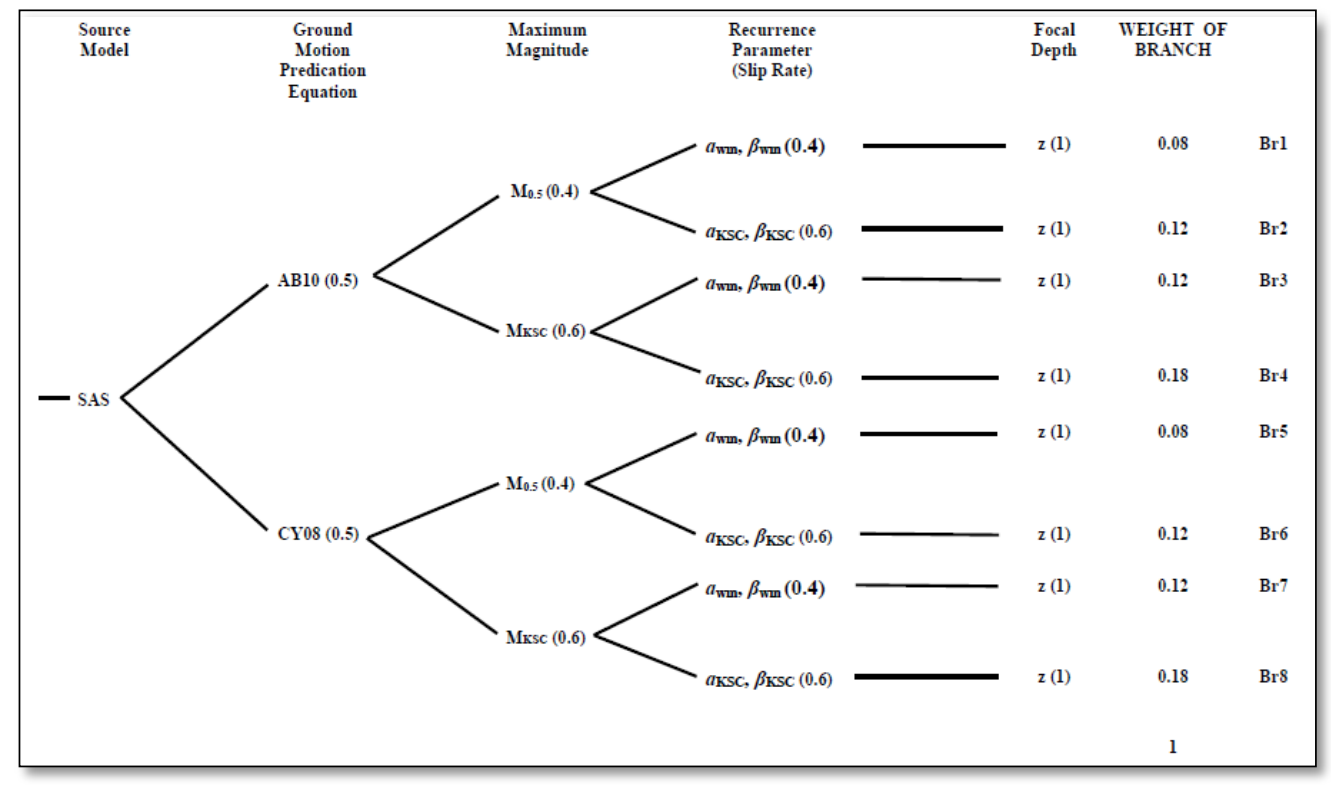

Figure 5: A sample of a logic tree diagram used for handling the uncertainties of parameters in the PSHA for NTD. The descriptions of acronyms at each node of the logic tree's branches are as follows: SAS $=$ Shallow Areal Source, ASB14 = Akkar et al. (2014), CY14 = Chiou and Youngs (2014), $\mathrm{M}_{0.5}=$ Maximum magnitude determined by adding 0.5 of a unit magnitude to the largest magnitude observed within a zone, $\mathrm{M}_{\mathrm{KSC}}=$ Maximum magnitude determined by Kijko's Statistical Code (Kijko 2004), $a_{w m}, \beta_{w m}$ and, $a_{K S C} \beta_{K S C}$ are a and $\beta(=-b l n 2.3)$ values determined by wizmap II software package and Kijko's Statistical Code, respectively, $\mathrm{z}=$ mean focal depth, $\mathrm{Br}=$ Branch number and numbers in the brackets are nodes' and branches' weights, respectively.

\section{Results and Discussions}

Results from this study are presented in contoured hazard maps in terms of peak ground acceleration $(\mathrm{PGA}$ at $\mathrm{T}=0.0 \mathrm{sec})$ and ground motion levels at two spectral ordinates $(\mathrm{T}=0.2$ sec and $2.0 \mathrm{sec}$ ) at bedrock sites (Figures 6, 7 and 8). The hazard maps for NTD show strong spatial variations ranging from 60 to 330 $\mathrm{cm} / \mathrm{s} / \mathrm{s}$ for PGA, from 100 to $650 \mathrm{~cm} / \mathrm{s} / \mathrm{s}$ at 0.2 sec and from 6 to $27 \mathrm{~cm} / \mathrm{s} / \mathrm{s}$ at $2 \mathrm{sec}$ for 475 
years mean return period and 5\% damping. The obtained results reflect the general tectonic setting of the studied area (Figures 6 and 7). From the two maps, it is evident that the hazard levels are restricted within the major rift structures in the western (Eyasi-Wembere) and central (Natron-Manyara-Barangida) rift segments. However, while the maps are indicating relatively high hazard levels in the western and central rift segments, the eastern
(Pangani) rift segment covering Kilimanjaro, and Masai block areas show relatively low values. The high and low values are attributed to high and low seismic activities within those zones, respectively. The spectral acceleration at the spectral ordinate of $2 \mathrm{sec}$ on the other hand is relatively low (Figure 8). This may be attributed to small and moderate earthquake events which are majority that occur within NTD having low energy in long period band.

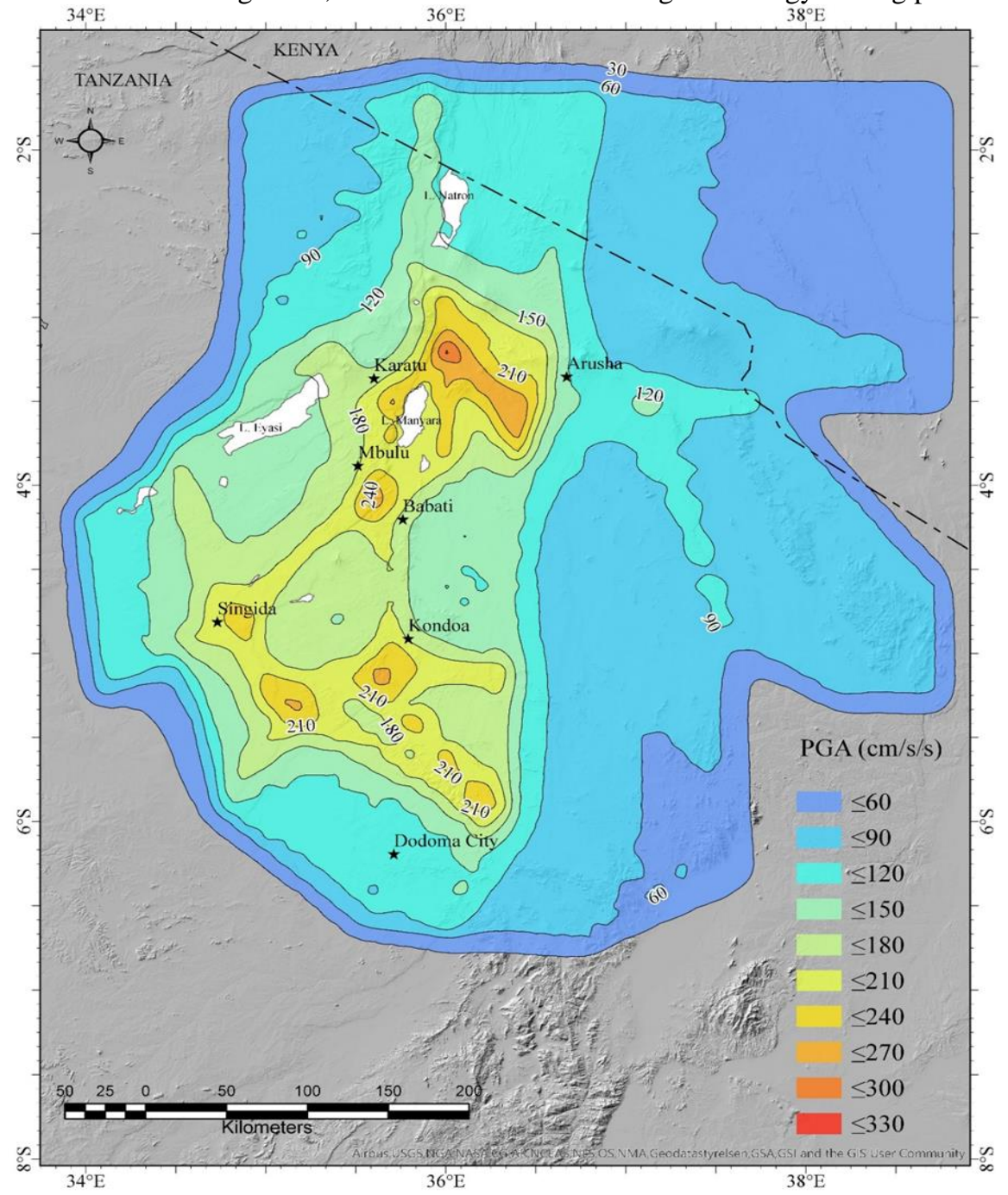

Figure 6: The ground shaking levels within the NTD at the spectral ordinate of 0.0 sec represented as PGA $(\mathrm{cm} / \mathrm{s} / \mathrm{s}), 5 \%$ damping and for 475 years return period (Contour interval: $30 \mathrm{~cm} / \mathrm{s} / \mathrm{s})$. 


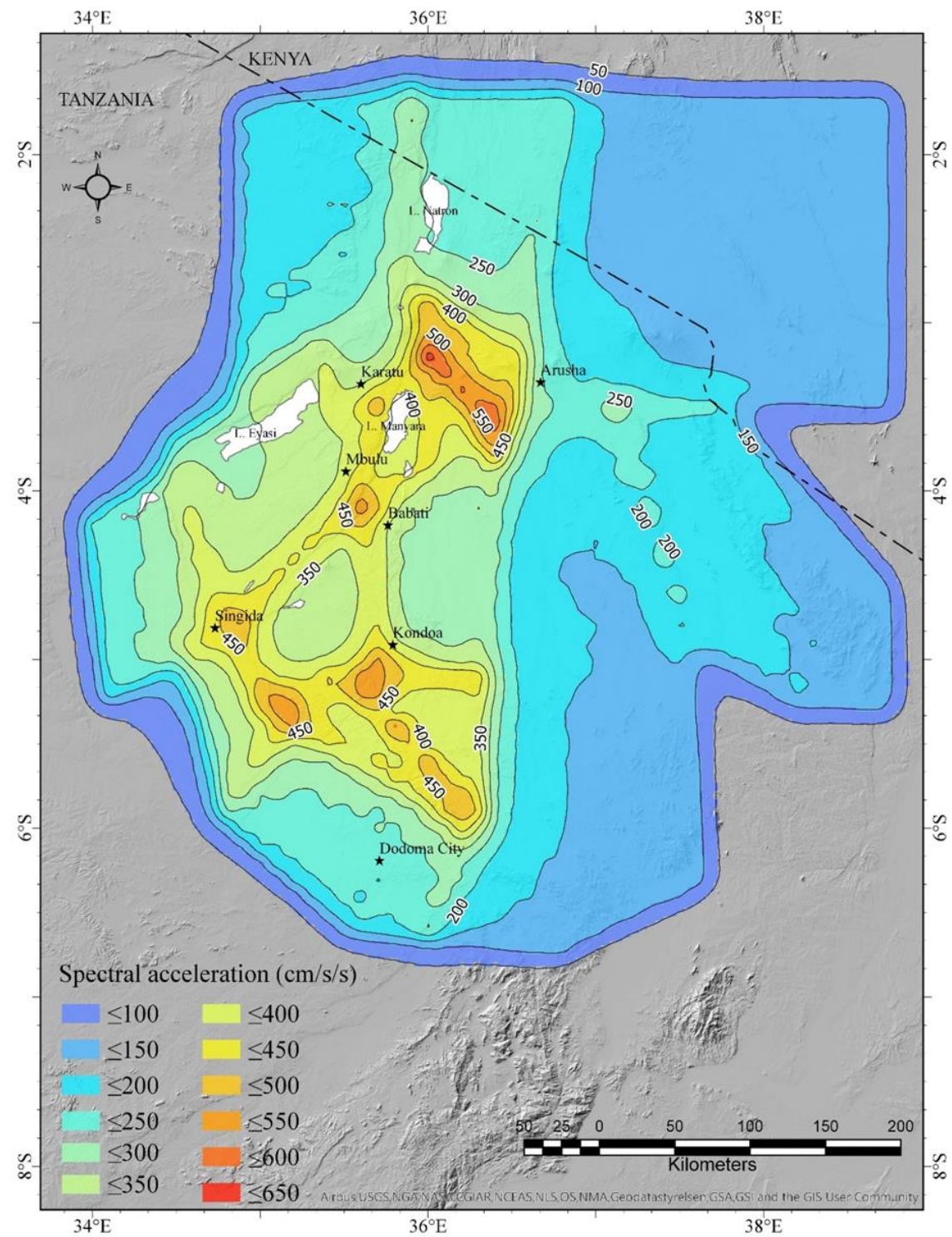

Figure 7: The ground shaking levels within the NTD at the spectral ordinate of $0.2 \mathrm{sec}$ represented as spectral acceleration $(\mathrm{cm} / \mathrm{s} / \mathrm{s}), 5 \%$ damping and for 475 years return period (Contour interval: $50 \mathrm{~cm} / \mathrm{s} / \mathrm{s}$ ). 


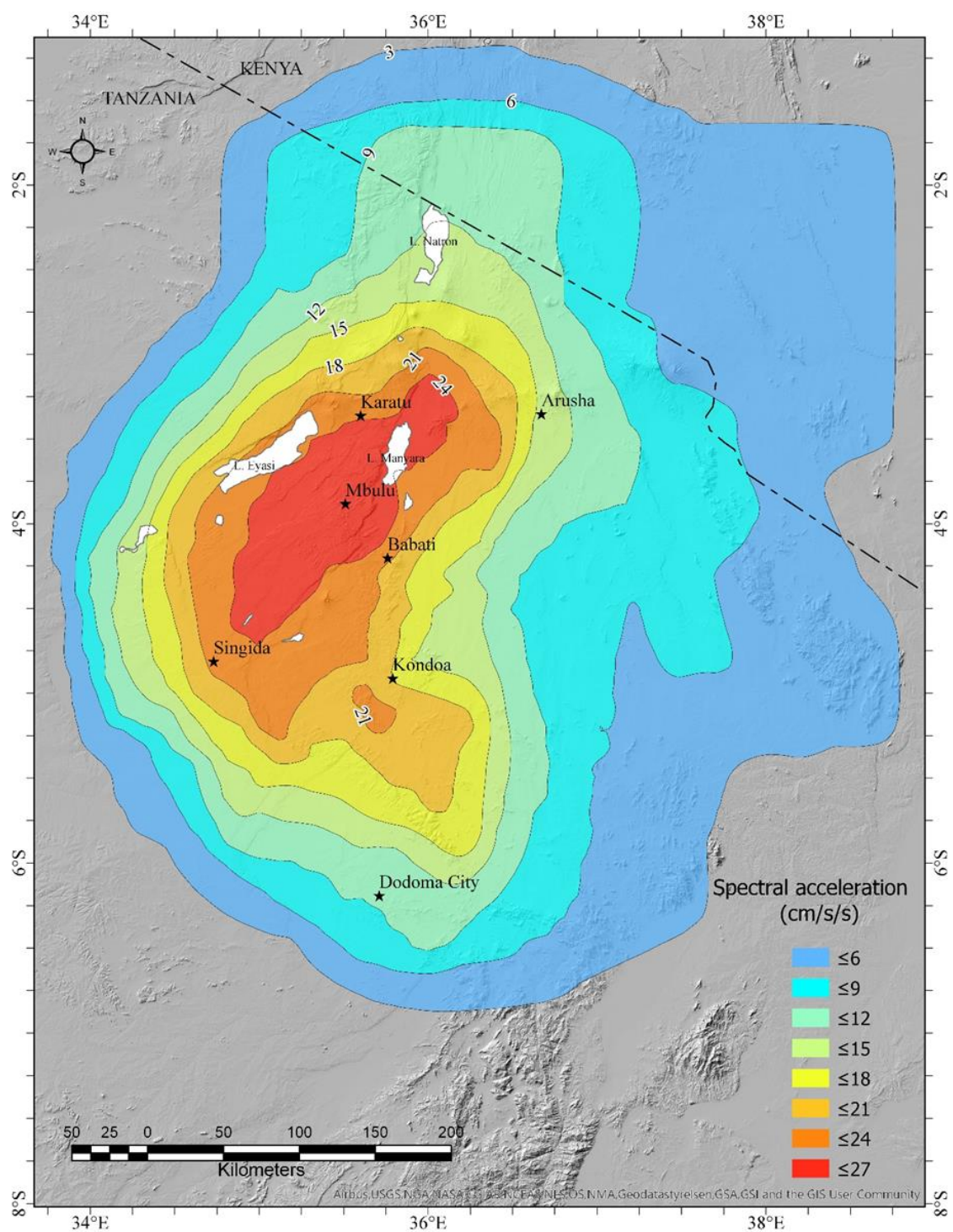

Figure 8: The ground-shaking levels within the NTD at the spectral ordinate of 2 seconds represented as spectral acceleration $(\mathrm{cm} / \mathrm{s} / \mathrm{s}), 5 \%$ damping, and for 475 years return period (Contour interval: $3 \mathrm{~cm} / \mathrm{s} / \mathrm{s}$ ).

As mentioned earlier in this work, NTD was part of the Global Seismic Hazard Analysis Project (GSHAP), whereby the area was regarded as a single seismic source (Midzi et al. 1999). With the same levels of seismic hazard estimates of $10 \%$ occurrence or exceedance within 50 years, the resulted PGA values were in a range of $160-220 \mathrm{~cm} / \mathrm{s} / \mathrm{s}$, which are low and narrow compared with results from this study (Figure 6). Mmari (1996) estimated the hazard mean at NTD at a PGA range of $384-390 \mathrm{~cm} / \mathrm{s} / \mathrm{s}$, which is slightly higher than the maximum PGA obtained in this study. The variations of the results from both studies are attributed to the GMPEs used and the mode of zonation, which were regarded 
NTD as a single zone. It can also be observed that with a single source zone, the variation in PGA is low as compared to multi-source in this study. This is supported by the results obtained by Poggi et al. (2016) who characterized NTD into three zones and obtained PGA values ranging from $80-320 \mathrm{~cm} / \mathrm{s} / \mathrm{s}$, which are comparable to the results of this study. In addition, the PGA values of $150 \mathrm{~cm} / \mathrm{s} / \mathrm{s}$ and $120 \mathrm{~cm} / \mathrm{s} / \mathrm{s}$ for cities of Arusha and Dodoma, respectively located within the rift, compared well with the results reported by Lubkowski et al. (2014).

The PSHA results for NTD area discussed above should be applied taking into consideration some limitations. Knowledge of seismic source geometries, i.e., active faults and the attenuation relation parameters for the strong-motion is lacking for the entire NTD area and surrounding area. The resulting hazard maps from the present work denote ground motion on rock and cannot predict specific site response due to subsurface sediments. Further PSHA studies should consider adding sitespecific parameters in order to obtain probabilities for specific site responses. The current analysis assumes the location of future earthquakes to be at the defined seismic zones. This could be tricky because certain parts within the NTD seem to have less earthquake activities, e.g., the Masai block, and Pangani rift segment. This could sometimes mean a slow strain buildup process on a strong lithosphere or that, the strain energy is accommodated somewhere else within the NTD. Hence the deployment of more seismographs stations and studying of active faulting in such areas is highly recommended. The short time history of the catalogue used in this study may limit the occurrence of large events in low strain accumulation in areas like Masai block. This is because some large events might have a recurrence period longer than the length of the used catalogue.

\section{Conclusions}

The outputs of this study are the seismic hazard maps for a return period of 475 years in terms of horizontal maximum PGA of 330 $\mathrm{cm} / \mathrm{s} / \mathrm{s}$, maximum spectral accelerations at $\mathrm{T}=$ 0.2 and $\mathrm{T}=2.0$ seconds, of $650 \mathrm{~cm} / \mathrm{s} / \mathrm{s}$ and 27 $\mathrm{cm} / \mathrm{s} / \mathrm{s}$, respectively, for bedrock site conditions. The calculated hazard is significant to construction engineers in understanding the short periods $(\mathrm{T}=0.2$ seconds $)$ and long periods ( $\mathrm{T}=2.0$ seconds) responses within NTD and the areas within its vicinity. This study obtained a consistent relatively high hazard level in the PGA and SA (at T $=0.2$ seconds) at western and central rift segments as compared with relatively low hazard levels in the eastern rift segment. Cities and towns that show high acceleration values are located along the earlier mentioned rift segments, that is, Arusha, Dodoma, Singida, Kondoa, Babati, and Karatu.

As estimates of hazard levels are key input parameters into the assessments of seismic risks, which yield estimates of property and lives losses from earthquakes, the results from this study allow policymakers to get an idea of seismic hazards in the area for planning purposes. Therefore, it is advisable that in designing major infrastructures within the NTD, earthquake effects should be taken into consideration. Since there is currently no earthquake building code for NTD, it is recommended to consider this target for informing earthquake-resistant design engineers. This work is the first step towards achieving the informed earthquake-resistant designs in the NTD.

\section{Acknowledgment}

This work was carried out at the Department of Geology, the University of Dodoma, and the Department of Geosciences (formerly Department of Geology), University of Dar es Salaam, as part of a PhD study funded by the Sida bilateral project support. Our sincere gratitude is to Roger Musson and Mario Ordaz for freely availing of R-CRISIS and Wizmap II software, respectively, for users. We thank Andrzej Kijko for providing MatLab scripts for statistical earthquake 
catalogue analysis. Most of the figures have been plotted with ArcGIS Pro.

\section{References}

Abrahamson NA and Shedlock KM 1997 Overview. Seis. Res. Let. 68(1): 9-23.

Akkar S, Sandikkaya MA and Bommer JJ 2014 Empirical ground-motion models for point- and extended-source crustal earthquake scenarios in Europe and the Middle East. Bull. Earthquake Eng. 12(1): 359-387.

Ambraseys NN 1991 The Rukwa earthquake of 13 December 1910 in East Africa. Terra Nova 3(2): 202-211.

Bommer J, Scherbaum F, Bungum H, Cotton F, Sabetta F and Abrahamson N 2005 On the use of logic-trees for ground-motion prediction equations in seismic-hazard analysis. Bull. Seismol. Soc. Am. 95(2): 377-389.

Bommer JJ, Douglas J, Scherbaum F, Cotton F, Bungum H and Fäh D 2010 On the selection of ground-motion prediction equations for seismic hazard analysis. Seismol. Res. Lett. 81(5): 783793.

Bouhadad Y, Nour A, Slimani A, Laouami N and Belhai D 2004 The Boumerdès (Algeria) earthquake of May 21, $2003(\mathrm{Mw}=6.8)$ : Ground deformation and intensity. J. Seismol. 8(4): 497-506.

Brazier RA, Nyblade AA and Florentin J 2005 Focal mechanisms and the stress regime in NE and SW Tanzania, East Africa. Geophy. Res. Lett. 32: L14315.

Bungum H and Ringdal F 1982 Stiegler's gorge power project. Seismic risk analysis phase II, Tanzania. NORSAR Technical Report. 1/82, NTNF/NORSAR, Kjeller, Norway.

Chiou BSJ and Youngs RR 2014 Update of the Chiou and Youngs NGA model for the average horizontal component of peak ground motion and response spectra. Earthquake Spectra 30 (3): $1117-1153$.

Cornell CA 1968 Engineering seismic risk analysis. Bull. Seismol. Soc. Am. 58: 1583-1606.

Cornell CA 1971 Probabilistic analysis of damage to structures under seismic loads. In: Howells DA, Haigh IP and Taylor C (Eds) Dynamic Waves in Civil Engineering. Proceedings of a Conference Organized by the Society for Earthquake and Civil Engineering Dynamics, John Wiley, New York.

Daudi GM 2007 Investigation of the seismo-tectonic structure of the eastern branch of the East
African Rift System in Tanzania. MSc thesis, University of Dar es Salaam, Tanzania.

Dawson JB 1992 Neogene tectonics and volcanicity in the northern Tanzania sector of the Gregory rift valley: Contrasts with the Kenya rift sector. Tectonophysics 204: 81- 92.

DDCA (Drilling and Dam Construction Agency) 2002 Water-well Sakina, Arusha. Borehole completion Report AR 91/2002.

Douglas J 2003 Earthquake ground motion estimation using strong-motion records: A review of equations for the estimation of peak ground acceleration and response spectral ordinates. Earth-Sci. Rev. 61(1-2): 43-104.

Ebinger CJ, Poudjom Y, Mbede E, Foster F and Dawson JB 1997 Rifting Archean lithosphere: The Eyasi-Manyara-Natron rifts, East Africa. $J$. Geol. Soc. Lon. 154: 947-960.

EERI 2003 The Boumerdes, Algeria Earthquake, May 21, 2003. Earthquake. Engineering. Res. Institute, Oakland, California, $57 \mathrm{p}$.

Fairhead JD and Stuart GW 1982 The seismicity of the East African rift system and comparison with other continental rifts. Continent. Oceanic Rifts 8: 41-61.

Ferdinand RW, Lupogo KP and Mulibo GD 2018 Evaluation of the ground response of the King Mohamed VI stadium Dodoma, Tanzania, Technical Report 2/2018.

Ferdinand RW, Lupogo KP, Mulibo GD and Melchiory S 2020 Seismic hazard and site analyses for the Government City-Mtumba, Dodoma (Phase I). Technical Report 4/2020.

Ferdinand RW, Mulibo GD, Nderimo FL and Lupogo K 2017 September $10^{\text {th }} 2016$ Kagera, magnitude 5.9 earthquake. Technical Report $1 / 2017$.

Ferdinand RW, Nderimo FL, Mbogoni G, Mtolela K and Mgimbwa F 2007 The Lake Natron (Oldonyo Gelai) magnitude 5.9 earthquake, July $17^{\text {th }}$ 2007. Report 2/2007.

Ferdinard RW and Nderimo FL 2007 The evaluation of earthquake resistance of the Arusha International Conference Centre (AICC). Technical Report. 1/2007.

Fontijn K, Delvaux D, Ernst GG, Kervyn M, Mbede E and Jacobs P 2010 Tectonic control over active volcanism at a range of scales: Case of the Rungwe Volcanic Province, SW Tanzania; and hazard implications. J. Afr. Earth Sci. 58(5): 764-777.

Foster AN and Jackson JA 1998 Source parameters of large African earthquakes: implications for 
Msabi and Ferdinand - Probabilistic seismic hazard analysis for Northern Tanzania ...

crustal rheology and regional kinematics. Geophy. J. Int. 134: 422-448.

Foster AN, Ebinger CJ, Mbede E and Rex D 1997 Tectonic development of the northern Tanzanian sector of the East African Rift System. J. Geol. Soc. Lon. 154: 689-700.

Gardner JK and Knopoff L 1974 Is the sequence of earthquakes in Southern California, with aftershocks removed, Poissonian? Bull. Seismol. Soc. Am. 64: 1363-1367.

Gutenberg R and Richter CF 1944 Frequency of earthquakes in California. Bull. Seismol. Soc. Am. 34: 185-188.

Hollnack D 1996 Kenya Seismological Network. Seismological Bulletin, University of Nairobi, Kenya.

Hollnack D and Stangl R 1998 The seismicity related to the southern part of the Kenya rift. $J$. Afr. Earth Sci. 26: 477-495.

Iranga MD 1991 An earthquake catalogue for Tanzania 1846-1988, Report No. 1-91, Seismological Department, Uppsala, Sweden.

Kijko A 2004 Estimation of the maximum earthquake magnitude, $m_{\max }$. Pure Appl. Geophys. 161: 1655-1681.

Lubkowski Z, Villani M, Coates K, Jirouskova N and Willis M 2014 Seismic design considerations for East Africa, In: Second European Conference on Earthquake Engineering and Seismology, Istanbul, August 2014, pg. 12.

McConnell RB 1972 Geological development of the rift system of eastern Africa. Geol. Soc. Am. Bull. 83: 2549-2572.

McGuire RK 1976 FORTRAN Computer program for seismic risk analysis, US Geol. Survey Open-File Report No. 76-67.

Midzi V, Hlatyawayo JD, Chapola LS, Kebede F, Atakan K, Lombe DK, Turyomurugyendo G and Tugume FA 1999 Seismic hazard assessment in Eastern and Southern Africa. Ann. Geophy. 42(6): 1067-1083.

Mmari AG 1996 Source characteristics and attenuation of seismic waves along Rukwa Rift zone and seismic hazard assessment of Tanzania, MSc thesis, Department of Earth
Science (GEO), University of Bergen (UiB), Norway.

Msabi MM 2010 Seismic source characterization for Northern Tanzania divergence. MSc thesis, University of Dar es Salaam, Tanzania.

Msabi MM 2016 Probabilistic seismic hazard analysis for the northern Tanzania Divergence. $\mathrm{PhD}$ University of Dar es Salaam, Tanzania.

Mulibo GD, 2012 Investigation of mantle structure beneath Eastern Africa: implications for the origin of the Cenozoic tectonism and propagation of the rift system. PhD thesis, The Pennsylvania State Univerity.

Mulibo GD 2019 Investigation of macroseismic intensity of the $\mathrm{Mw}=5.9$ September 10, 2016 Kagera earthquake: Implications for site effect amplification. J. Afr. Earth Sci. 159: 103568.

Musson RMW 1998 Historical seismicity of the Western Frontier Area, British Geological Survey Technical Report WL/94/26c.

NHBRU 2015 Loads for Structural Design. NHBRU Technical Guideline No. 2 ( $2^{\text {nd }}$ ed. $), 70$ pp; www.nhbra.go.tz

Nyblade AA and Langston CA 1995 East African earthquake below $20 \mathrm{~km}$ depth and their implications for crustal structure. Geophy. J. Int. 121: 49-62.

Nyblade AA, Langston CA, Last RJ, Birt C and Owens TJ and 1996 Seismic experiment reveals rifting of Craton in Tanzania. Eos Trans. Am. Geophys. Union (AGU) 77: 517-521.

Ordaz M and Salgado-Gálvez MA 2019 R-CRISIS validation and verification document. ERN Technical Report. Mexico City, Mexico, pg. 310.

Poggi V, Durrheim R, Tuluka GM, Pagani M, Weatherill G, Gracia J and Nyblade AA 2016 A seismic hazard model for Sub Saharan Africa. GEM Technical Report, Pavia, 50 pp.

Shudofsky GN 1985 Source mechanisms and focal depths of East African earthquakes using Rayleigh-wave inversion and body-wave modelling. Geophys. J. Int. 83: 563-614.

Weichert DH 1980 Estimation of the earthquake recurrence parameters for unequal observation periods for different magnitudes. Bull. Seismol. Soc. Am. 70(4): 1337-1346. 